Authors: Anna Zawada-Tomkiewicz, Krzysztof Zieliński, Łukasz Żurawski

Title of article: „Analiza mechanizmów zużycia piły tarczowej” („Analysis of wear mechanisms of circular saw blades”)

Mechanik, Vol. 91, No. 10 (2018): pages 892-894

DOI: https://doi.org/10.17814/mechanik.2018.10.155

\title{
Analysis of wear mechanisms of circular saw blades
}

\section{Analiza mechanizmów zużycia ostrzy piły tarczowej}

\section{ANNA ZAWADA-TOMKIEWICZ KRZYSZTOF ZIELIŃSKI ŁUKASZ ŻURAWSKI *}

The work is devoted to the machinability problems of selected grades of steel in the conditions of cutting rods with a circular saw. Selected indicators of machinability of steels were tested in industrial conditions. Attempts to cut steel were carried out on a BLM EM 80 CNC machining center. The analysis covered the tool wear during cutting of $\mathrm{C} 35 \mathrm{EC}, \mathrm{Pb}$ $30,16 \mathrm{MnCrSPb} 5, \mathrm{~S} 355 \mathrm{~J} 2+\mathrm{C}$. The tool (circular saw) was measured before and after machining of steel.

KEYWORDS: tool wear, circular saw, machinability

Circular saws are used in circular sawing machines for material cutting. The tool is a disk with a large diameter and small thickness. Fig. 1a presents an example of a saw blade in relation to a workpiece mounted in a rotary head with hydraulically clamped jaws.
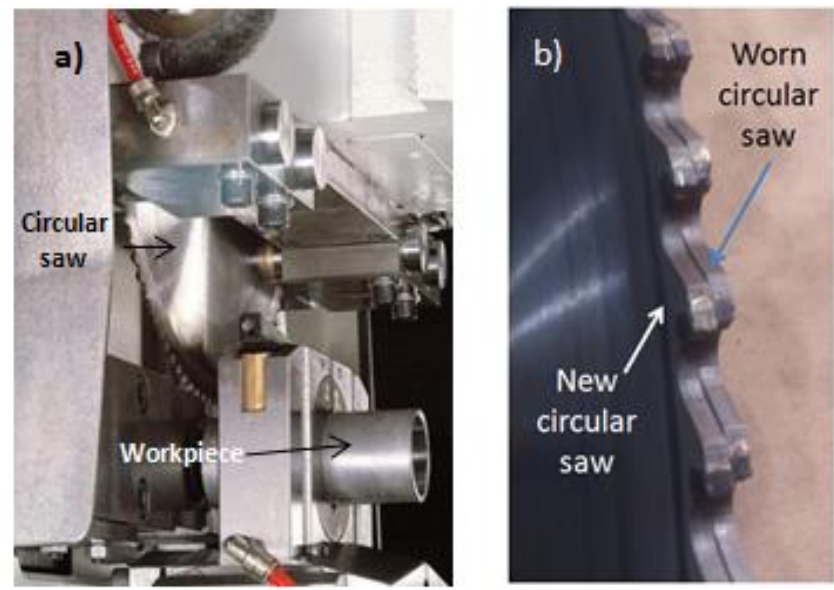

Fig. 1. Adjustment of the workpiece relative to the circular saw (a), view of the new and used saw blades (b)

Circular saws can have blades made of high-speed steel or sintered carbides. The blades are specially ground on the side surfaces (inclination of the auxiliary flank), which is designed to reduce friction and to facilitate the access of cutting fluid. Thanks to the use of sintered carbide blades, it is possible to perform high-speed machining and cutting difficult-to-cut materials [1-2].

\footnotetext{
* Prof. nadzw. dr hab. inż. Anna Zawada-Tomkiewicz (anna.zawada-tomkiewicz@tu.koszalin.pl), mgr inż. Krzysztof Zieliński (rummel@wp.pl), dr inż. Łukasz Żurawski (lukasz.zurawski@tu.koszalin.pl) - Katedra Inżynierii Systemów Technicznych i Informatycznych, Wydział Mechaniczny Politechniki Koszalińskiej
}

The circular saw is a multi-pointed tool in which the load on a single blade is cyclical and impact-like. As a result of the cutting process performed by successive saw blades, the shape of their edges is gradually changed. Some of the cutting blades are worn abrasive, part of them breaks and with time the saw stops to effectively cut the workpiece [3].

Fig. $1 \mathrm{~b}$ shows a view of the contact surface of the sintered carbide blades of the new and used circular saw blade. The criterion defining the tool life refers to the situation in which the cutting ability of the blades decreases, the cutting temperature increases, noise and vibrations increase and the shape of the blades changes over the assumed criterion [11].

The wear of the blades results in an abrasion of the flank $A_{\alpha}$, especially in the tool wedges, which causes them to be rounded. As a result of this natural wear, the obtuse angle of the whole blade is reduced [3]. The wear of the saw blades increases the transverse loads of the saw, which in turn affects the increase of its deformations and as a result, the gap of the kerf can widen [9].

The choice of cutting speed and feed rate determines the tool of each blade and the tool life of the circular saw. Additionally, the work material and its properties have the greatest impact on tool life [8].

An attempt was made to identify mechanisms of wear of circular saw blades, which included edge chipping and blunting of the blade, abrasive wear and adhesive wear. The intensity of each of these mechanisms is determined by the cutting parameters, the blade-work material and the cutting kinematic system. In the case of intermittent cutting, characteristic of a circular saw, the geometry of the blade entry into the material and the output from it is important because of the increased impact load in these phases of work.

\section{Research methodology}

The aim of the research was to determine mechanisms of wear and damage of the circular saw in the processes of cutting various steel grades (C35EC, Pb-30, 16MnCrSPb5 and S355J2 $+\mathrm{C}$ ). The tests were carried out in industrial conditions. The methodology of cutting steel is presented in the tab. I.

After the cutting tests, the blades were photographed using a microscopic measurement system and the values of wear indicators were determined. Every fifth blade of four circular saws was analyzed. The measurement methodology is included in the tab. II. 


\section{TABLE I. Specification of the cutting process} Tool

- Kanefusa Ferro Max Speed circular saw for cutting solid material and steel pipes; blades made of coated cemented carbide

- Cutting parameters (manufacturer's recommendations): cutting speed $200 \div 300 \mathrm{~m} / \mathrm{min}$, feed $0.05 \div 0.08$ $\mathrm{mm} /$ blade

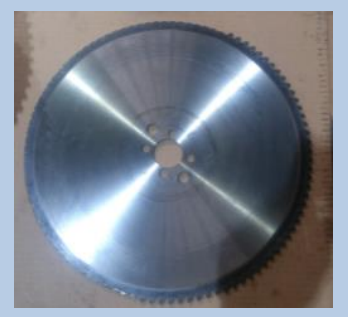

$D=315 \mathrm{~mm}, B=2,5 \mathrm{~mm}, b=2,3 \mathrm{~mm}, d=50 \mathrm{~mm}, z=120$ lub 100.

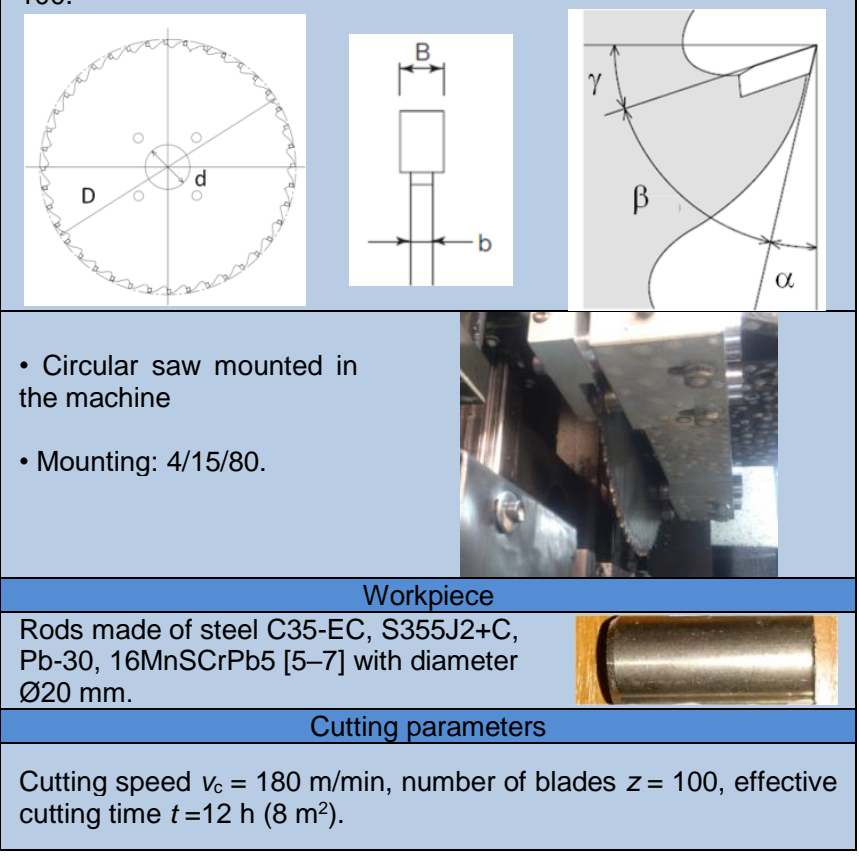

TABLE II. Specification of measurements

Optical system for measuring the blade wear

Microscopic measuring system was used, which is composed of the digital camera, lens, lighting system, computer with image acquisition card and software for digital image processing, identification and measurements of selected dimensional and shape parameters $[10,12]$

\section{Measurement strategy}

Every fifth blade was measured successively. For each blade measurements of minor flank $A_{\alpha 1}$ and $A_{a 2}$ surfaces were made. The measurement required taking a series of images $(1 \mathrm{~mm} \times 1$ $\mathrm{mm}$ ) and their stitching
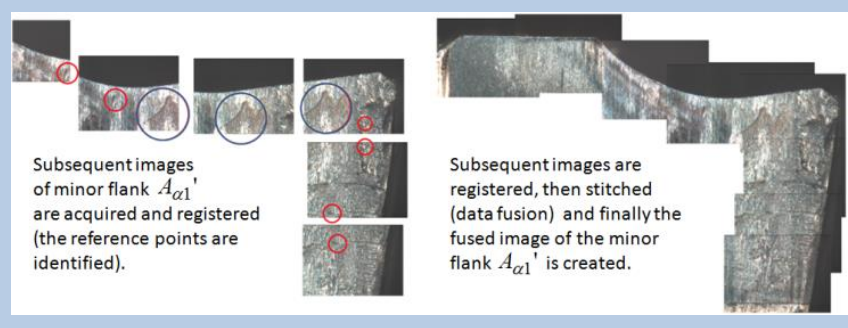

\section{Mechanisms of blade wear}

Analysis of the images of the surface of the circular saw blades pointed to brittle fracture and breakage of the blades. The intensity of phenomena in individual trials was compiled in tab. III.

Where there was no breaking of the blades, very intensive abrasion and adhesive wear was visible, characterized by craters, notches, scratches, cuts and scaly signs of wear of the flank surface from the cutting edge. It is visible on the major and minor flank surfaces (fig. 2 and fig. $3)$, where the shortening of the blade is marked with black.

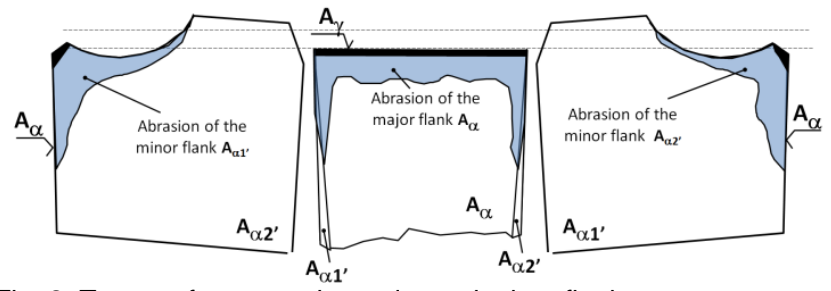

Fig. 2. Traces of wear on the major and minor flanks
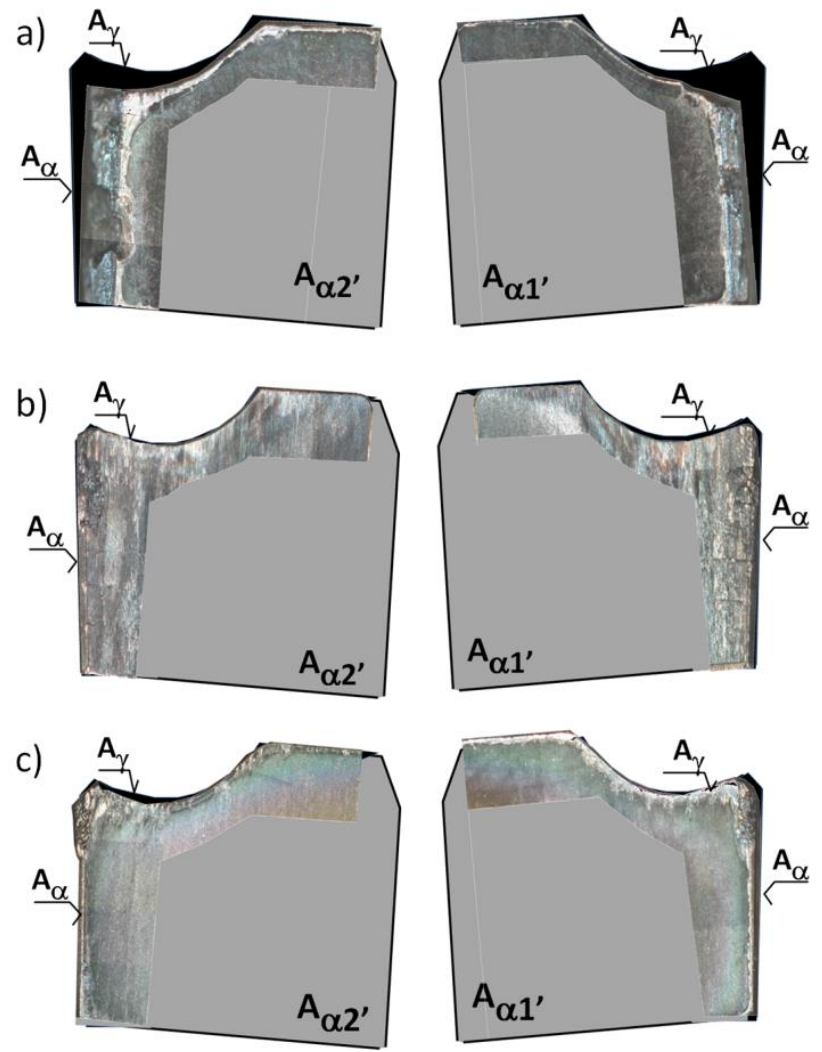

Fig. 3. Traces of wear on the minor flanks Aa1 and Aa2 circular saw blade for steel: a) C35EC, b) S355J2 + C, c) 16MnSCrPb5 and Pb30

Wear in the form of rounding of the cutting edge and blunting of the blades was noticeable for all not broken blades and was mainly abrasive in character. Locally, there was observed a build-up edge on the blade (fig. $3 b$ and fig. 3c).

In the furrows and in the vicinity of the cutting edge, temperature changes and the oxidized cut material were observed. Identification of traces of oxidation and mechanism of corrosion wear was difficult due to the extensive covering of the blade surface with workpiece material. The fatigue mechanism was identified by the occurrence of wear and adhesion successively. The presence of microcracks contributed to the edge grooving under variable cutting force conditions during circular saw cutting cycles. 


\section{Edge chipping and blunting of the blade}

Under the influence of periodic loading of the blade surface in the conditions of intermittent cut with a circular saw at the cutting edge, fatigue micro cracks were initiated, which gradually or rapidly developed, leading to microcrushing and chipping of the blade material (figs. 4b-5). A notch on the surface parallel to the main cutting edge was also observed. The edge chipping is particularly large when there is observed BUE (build-up edge) and BUL (build-up layer).

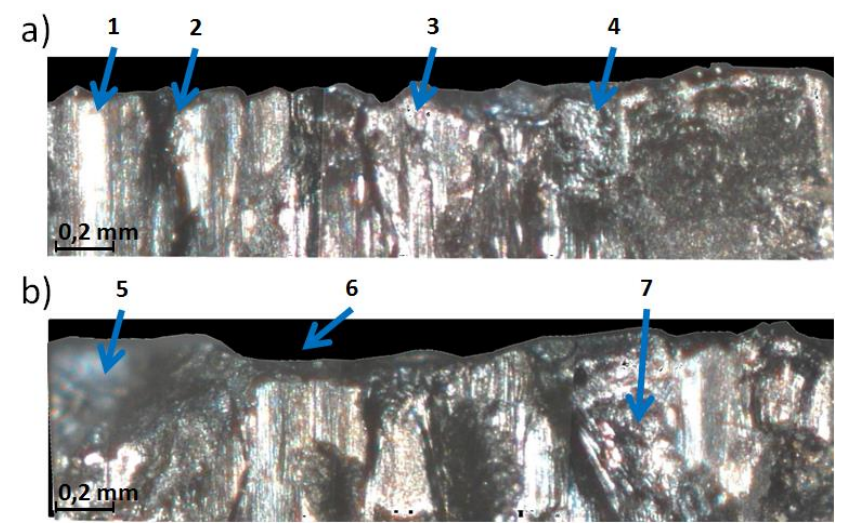

Fig. 4. Traces of wear of the major flank of the circular saw blade for the cut material: a) C35EC, b) $\mathrm{S} 355 \mathrm{~J} 2+\mathrm{C}$

\section{Adhesive wear}

Adhesive wear occurs at the interface between the tool and the workpiece. As a result of mutual movement, fragments of the surface of the tool and workpiece are in a short-term contact in the micro-roughness range and when transferring from contact, the material is transferred from one surface to the other.

At the range of cutting speed assumed in the presented tests, the material flow was irregular and the local microseal between the material of the tool and the workpiece formed cyclically during cutting and were cut at the same time due to the relative sliding in the tool-work interface.

In the case of steel cutting, the shear of a circular saw blade made of sintered carbide takes place mainly in steel, with much less probability - in the blade. This mechanism is often referred to as plucking or abrasion. This wear was identified by the presence of shallow craters on the surface of the cutting edges (figs. 4a-4).

\section{Abrasive wear}

Abrasive wear of tools results from the presence of harder inserts in the machined material than the tool. The wear mechanism includes the destruction of the tool material by the friction action of the hard phase inclusion found in the material and the chip (hard carbides, oxides and nitrides).

The mechanism of abrasive wear consists in creating a local plastic deformation of the surface layers of the cutting tool, where the material is pushed through the hard particle and where the plow takes place in the softer blade material (figs. 4a-1, 2). If the inclusions are spherical, traces remain in the tool material. If the inclusions are very sharp, they can cause micro-scratching and lapping or grinding effect [3].

The abrasive wear was observed both on the abrasive wear blades and on the blades that had previously crumbled or broken.

\section{Conclusions}

Depending on the steel grade, various wear mechanisms were observed for the circular saw blades. However, each time there were abrasion traces on the minor flanks.

Tab. III shows the intensity of phenomena for the tested steel grades. It shows that:

- The C35EC high carbon steel favored rapid wear of the blades in the circular saw, and many blades were broken. In the case of steel grades with a lower content of carbon, depending on the content, there was observed a build-up edge on the blades, and the worn blades were covered with machined material. The formation of BUE provided protection for the blades and thus the width of the abrasion on flanks was smaller.

- The average wear value VB of circular saw blades was obtained for S355J2 + C steel. Abrasive wear of the blades was caused by the addition of silicon and chromium in steel. The low carbon content in steel caused, on the other hand, that there was a BUE on the blades and that they were heavily covered with the cut material.

- The lowest abrasive wear of circular saw blades for Pb30 and $16 \mathrm{MnCrSPb5}$ steel; they also did not break off.

The abrasive wear at the edge and on the flank of all blades was high. This was the result of using a high cutting speed and a small thickness of the machined layer.

The high wear rate of minor flanks resulted from the abrasive properties of the work material and the presence of alloy additives. Chipping on the edge and breakage of the blades were caused by the heavy load of the blades, as well as the hardness of the workpiece and the presence of hard inclusions.

TABLE III. Assessment of the severity of the wear phenomenon of circular saw blades

\begin{tabular}{|c|c|c|c|c|c|}
\hline Steel grade & \multicolumn{2}{|l|}{$\begin{array}{l}\text { Breakage of } \\
\text { the blades }\end{array}$} & $\begin{array}{c}\text { Width of } \\
\text { abrasion on } \\
\text { the minor flank }\end{array}$ & BUE or BUL \\
\hline C35EC & $10 \%$ & ${ }^{* *}$ & $3 \mathrm{~mm}$ & ${ }^{* * *}$ & - \\
\hline $\mathrm{S} 355 \mathrm{~J} 2+\mathrm{C}$ & $5 \%$ & ${ }^{*}$ & $1,5 \mathrm{~mm}$ & ${ }^{* *}$ & ${ }^{* *}$ \\
\hline $\mathrm{Pb}-30$ & $<1 \%$ & ${ }^{*}$ & $1 \mathrm{~mm}$ & ${ }^{*}$ & ${ }^{*}$ \\
\hline $16 \mathrm{MnSCrPb5}$ & $<1 \%$ & ${ }^{*}$ & $1 \mathrm{~mm}$ & ${ }^{*}$ & ${ }^{*}$ \\
\hline \\
Legend: ${ }^{* *}$ high intensity of phenomena, ${ }^{* *}$ medium inten- \\
sity of phenomena, ${ }^{*}$ low intensity of phenomena \\
\hline
\end{tabular}

\section{REFERENCES}

1. Cichosz P. „Narzędzia skrawające”. Warszawa: WNT, 2006.

2. Grzesik W. „Podstawy skrawania materiałów konstrukcyjnych”. Warszawa: WNT, 2010.

3. Hughes J., Sharman A., Ridgway K. "The effect of cutting tool material and edge geometry on tool life and workpiece surface integrity". Proc Inst Mech Eng Part B J Eng Manuf (2006).

4. Materiały informacyjne firmy Kanefusa.

5. PN-EN ISO 683-2:2018-08. Stale do obróbki cieplnej, stale stopowe i stale automatowe - Część 2: Stale stopowe do hartowania i odpuszczania.

6. PN-EN 10087:2000. Stal automatowa - Warunki techniczne dostawy półwyrobów, prętów i walcówki walcowanych na gorąco.

7. PN-EN 10277:2018-09. Wyroby stalowe o powierzchni jasnej Warunki techniczne dostawy.

8. Tavodova M. i in. "Analysis of the wear of saw blade teeth and the proposal of methods of increasing their wear resistance". MM Science Journal. (2016): pp. 1287-1291.

9. Wasilewski R. „Dokładne $i$ oszczędne przecinanie drewna piłami tarczowymi". Gdańsk: Wydawnictwo Politechniki Gdańskiej 2011.

10. Wierucka I., Zawada-Tomkiewicz A., Łukianowicz Cz. „Ocena przydatności wybranych optycznych systemów pomiarowych w 
procesie wytwarzania i eksploatacji części maszyn”. Mechanik. 7 (2013): pp. 538-543.

11. Zawada-Tomkiewicz A., Storch B. „Zużycie ostrza z uwzględnieniem warunków cieplnych". Mechanik. 8 (2011): pp. 140151.

12. Zawada-Tomkiewicz A., Żurawski Ł. „Obrabiarki, narzędzia i procesy obróbki skrawaniem. Ćwiczenia laboratoryjne". Koszalin: Wydawnictwo Uczelniane Politechniki Koszalińskiej, 2015.

Translation of scientific articles, their computer composition and publishing them on the website www.mechanik.media.pl by original articles in Polish is a task financed from the funds of the Ministry of Science and Higher Education designated for dissemination of science.

Ministry of Science and Higher Education

Republic of Poland 